\title{
Review \\ The Framework for Human Host Immune Responses to Four Types of Parasitic Infections and Relevant Key JAK/ STAT Signaling
}

\author{
Tsung-Han Wen ${ }^{1,+}$, Kuo-Wang Tsai ${ }^{2} \mathbb{D}$, Yan-Jun Wu ${ }^{3,+}$, Min-Tser Liao ${ }^{3}$, Kuo-Cheng Lu 4 \\ and Wan-Chung $\mathrm{Hu}^{5, *(\mathrm{D})}$
}

1 Department of Anatomical Pathology, Taipei Tzu Chi Hospital, Buddhist Tzu Chi Medical Foundation, New Taipei City 231, Taiwan; ashin1258@gmail.com

2 Department of Medical Research, Taipei Tzu Chi Hospital, Buddhist Tzu Chi Medical Foundation, New Taipei City 231, Taiwan; kwtsai6733@gmail.com

3 Department of Pediatrics, Taoyuan Armed Forces General Hospital, Taoyuan City 325, Taiwan; wuyanjun@aftygh.gov.tw (Y.-J.W.); liao-ped804h@yahoo.com.tw (M.-T.L.)

4 Division of Nephrology, Department of Medicine, Fu-Jen Catholic University Hospital, School of Medicine, Fu-Jen Catholic University, New Taipei City 242, Taiwan; kuochenglu@gmail.com

5 Department of Clinical Pathology \& Medical Research, Taipei Tzu Chi Hospital, Buddhist Tzu Chi Medical Foundation No. 289, Jianguo Road, Xindian District, New Taipei City 231, Taiwan

* Correspondence: Wanchung.Hu09@gmail.com; Tel.: +886-2-89676779

+ These authors contributed equally to this work.

check for

updates

Citation: Wen, T.-H.; Tsai, K.-W.; Wu, Y.-J.; Liao, M.-T.; Lu, K.-C.; Hu, W.-C. The Framework for Human Host Immune Responses to Four Types of Parasitic Infections and Relevant Key JAK/STAT Signaling. Int. J. Mol. Sci. 2021, 22, 13310. https://doi.org/10.3390/ ijms222413310

Academic Editor: Andreas Burkovski

Received: 20 October 2021

Accepted: 8 December 2021

Published: 10 December 2021

Publisher's Note: MDPI stays neutral with regard to jurisdictional claims in published maps and institutional affiliations.

Copyright: (c) 2021 by the authors. Licensee MDPI, Basel, Switzerland. This article is an open access article distributed under the terms and conditions of the Creative Commons Attribution (CC BY) license (https:// creativecommons.org/licenses/by/ $4.0 /)$.
Abstract: The human host immune responses to parasitic infections are complex. They can be categorized into four immunological pathways mounted against four types of parasitic infections. For intracellular protozoa, the eradicable host immunological pathway is TH1 immunity involving macrophages (M1), interferon gamma (IFN $\gamma$ ) CD4 T cells, innate lymphoid cells 1 (NKp44+ ILC1), CD8 T cells (Effector-Memory4, EM4), invariant natural killer T cells 1 (iNKT1) cells, and immunoglobulin G3 (IgG3) B cells. For intracellular protozoa, the tolerable host immunological pathway is TH1-like immunity involving macrophages (M2), interferon gamma (IFN $\gamma$ )/TGF $\beta$ CD4 T cells, innate lymphoid cells 1 (NKp44- ILC1), CD8 T cells (EM3), invariant natural killer T 1 (iNKT1) cells, and immunoglobulin A1 (IgA1) B cells. For free-living extracellular protozoa, the eradicable host immunological pathway is TH22 immunity involving neutrophils (N1), interleukin-22 CD4 T cells, innate lymphoid cells 3 (NCR+ ILC3), iNKT17 cells, and IgG2 B cells. For free-living extracellular protozoa, the tolerable host immunological pathway is TH17 immunity involving neutrophils (N2), interleukin-17 CD4 T cells, innate lymphoid cells 3 (NCR- ILC3), iNKT17 cells, and IgA2 B cells. For endoparasites (helminths), the eradicable host immunological pathway is TH2a immunity with inflammatory eosinophils (iEOS), interleukin-5/interleukin-4 CD4 T cells, interleukin-25 induced inflammatory innate lymphoid cells 2 (iILC2), tryptase-positive mast cells (MCt), iNKT2 cells, and IgG4 B cells. For ectoparasites (parasitic insects and arachnids), the eradicable host immunological pathway is TH2b immunity with inflammatory basophils, chymase- and tryptase-positive mast cells (MCct), interleukin-3/interleukin-4 CD4 T cells, interleukin-33 induced nature innate lymphoid cells 2 (nILC2), iNKT2 cells, and immunoglobulin E (IgE) B cells. The tolerable host immunity against ectoparasites and endoparasites is TH9 immunity with regulatory eosinophils, regulatory basophils, interleukin-9 mast cells (MMC9), thymic stromal lymphopoietin induced innate lymphoid cells 2, interleukin-9 CD4 T cells, iNKT2 cells, and IgA2 B cells. In addition, specific transcription factors important for specific immune responses were listed. This JAK/STAT signaling is key to controlling or inducing different immunological pathways. In sum, Tfh is related to STAT5 $\beta$, and BCL6 expression. Treg is related to STAT5 $\alpha$, STAT5 $\beta$, and FOXP3. TH1 immunity is related to STAT $1 \alpha$, STAT4, and T-bet. TH2a immunity is related to STAT6, STAT1 $\alpha$, GATA1, and GATA3. TH2b immunity is related to STAT6, STAT3, GATA2, and GATA3. TH22 immunity is associated with both STAT $3 \alpha$ and AHR. TH $\alpha \beta$ immunity is related to STAT1 $\alpha$, STAT1 $\beta$, STAT2, STAT3 $\beta$, and ISGF. TH1-like immunity is related to STAT1 $\alpha$, STAT4, STAT5 $\alpha$, and STAT5 $\beta$. TH9 immunity is related to STAT6, STAT5 $\alpha$, STAT5 $\beta$, and PU.1. TH17 immunity is related to STAT3 $\alpha$, STAT5 $\alpha$, STAT5 $\beta$, and 
RORG. TH3 immunity is related to STAT $1 \alpha$, STAT $1 \beta$, STAT2, STAT3 $\beta$, STAT $5 \alpha$, STAT5 $\beta$, and ISGF. This categorization provides a complete framework of immunological pathways against four types of parasitic infections. This framework as well as relevant JAK/STAT signaling can provide useful knowledge to control allergic hypersensitivities and parasitic infections via development of vaccines or drugs in the near future.

Keywords: immune response; parasitic infection; eosinophils; mast cells; basophils; protozoa; helminths; parasitic insects; JAK/STAT

\section{Introduction}

Host immune responses to parasitic infections are complex. Parasites include protozoa, helminths, and insects. Previously, the author proposed a framework for all the known host immunological pathways and their roles in the immune responses against four specific types of pathogens and the corresponding four specific types of hypersensitivities [1,2]. In this framework, the author included TH1, TH2, TH3, TH9, TH17, TH22, Tfh, Treg, and $\operatorname{Tr} 1$ to describe their roles in eradicable immunity or tolerable immunity in detail [3-7]. Tfh cells are the $T$ helper cells that initiate eradicable immunity with $B$ cell antibody class switch to IgG. Treg cells are the Thelper cells that initiate tolerable immunity with B cell antibody class switch to IgA. TH1 immune response is the eradicable host immunity against intracellular pathogens including intracellular bacteria, fungi, or protozoa (intracellular microorganisms). TH1-like immune response is the tolerable host immunity against intracellular pathogens including intracellular bacteria, fungi, or protozoa (intracellular microorganisms). Both TH1 and TH1-like immunities are related to type 4 delayed-type hypersensitivity. TH2 immune response is the eradicable host immunity against helminths and insects. TH9 immune response is the tolerable host immunity against helminths and insects. Both TH2 and TH9 immunities are related to type 1 allergy hypersensitivity. TH22 immune response is the eradicable host immunity against extracellular bacteria, fungi, and protozoa (extracellular microorganisms). TH17 immune response is the tolerable host immunity against extracellular bacteria, fungi, and protozoa (extracellular microorganisms). Both TH22 and TH17 immunities are related to type 3 immune complex hypersensitivity. $\mathrm{TH} \alpha \beta$ (Tr1) immune response is the eradicable host immunity against viruses. TH3 immune response is the tolerable host immunity against viruses. Both $\mathrm{TH} \alpha \beta$ and TH3 immunities are related to type 2 antibody-dependent cytotoxic hypersensitivity. However, the TH2 host immunological pathway against parasites can be further divided into TH2a and $\mathrm{TH} 2 \mathrm{~b}$ to react to different pathogens, such as helminths and insects, respectively. Here, we extend the framework and propose a new framework of host immunological pathways for four types of parasitic infection. Host immunological pathways against parasites are determined primarily by the location of the infection. After identifying the location of the parasitic infection, the host immune system can attack these parasites with different effector cells using different strategies.

STAT proteins are master regulators of host immunological pathways [1]. After binding to receptors, different cytokines activate different JAK/STAT signaling pathways to trigger different immunological pathways in response to different pathogens [3-8]. STAT proteins are transcription factors, and they can compete with each other, leading to different host immunological pathways against specific pathogens. JAK/STAT signaling is the major downstream signaling of multiple cytokine receptors. Cytokine receptors can activate different JAK/STAT signaling pathways to mediate different immune functions. Here, we summarize these JAK/STAT signaling pathways and their roles in immune function as well as diseases, especially parasitic infections.

Eradicable immunological pathways are initiated by follicular helper T cells (Tfh) [9]. These $\mathrm{T}$ cells can secrete interleukin 21 to induce a B cell antibody class switch from IgM to IgG [10]. IgG is characteristic of eradicable host immune reactions. IL-21 receptor 
activation can induce JAK1/JAK3 signaling to activate STAT5 $\beta$ [11]. The magnitude of JAK1 activation by interleukin-21 is higher than that by interleukin-2 or interleukin-15 [12]. STAT1, STAT3, and STAT $5 \beta$ are the main transcription factors activated by interleukin 21 to mediate the function of follicular helper T cells. Afterwards, BCL6 is upregulated by STAT5 $\beta$ to initiate the function of follicular helper T cells. The eradicable immunological pathways can be categorized into four groups ( $\mathrm{TH} 1, \mathrm{TH} 22, \mathrm{TH} 2$, and $\mathrm{TH} \alpha \beta$ ) based on the subtypes of IgG antibodies and different pathogens.

The regulatory immunological pathway is initiated by regulatory CD4 T cells (Tregs) [9]. When the pathogen infection is diffuse involving an organ, strong eradicable immunity with IgG response will cause fulminant organ damage. Thus, milder regulatory immunity with IgA response is initiated to mildly control the pathogens to co-exist with these pathogens. For example, the mucosal immunity in the gastroenteric tract is the regulatory immunity to co-exist with Escherichia coli and other intestinal pathogens. If the host cannot eradicate the infection, Tregs will be triggered only to limit the infection and immune reaction. FOXP3 is a key transcription factor of regulatory CD4 T cells. STAT5 transcription factors, especially STAT $5 \alpha$, can upregulate FOXP3. TGF $\beta$ is the main cytokine that mediates Treg cell function. This can cause B cell antibody class switching to IgA antibodies. Interleukin-2 also plays a critical role in the development of regulatory $\mathrm{T}$ cells. Interleukin-2 receptors can activate JAK1 and JAK3 to phosphorylate STAT5 $\alpha$ and STAT5 $\beta$ and mediate Treg function $[13,14]$. Compared to interleukin-21, JAK3 signaling induced by interleukin-2 is stronger. Based on the type of pathogen, regulatory immunological pathways can also be categorized into four groups (TH1-like, TH17, TH9, and TH3).

\section{Host Immunological Pathways for Different Types of Parasitic Infections}

\subsection{Intracellular Protozoa and TH1/TH1-like Immunity}

For intracellular protozoa, the host immunological pathway is a TH1 immune response involving macrophages (M1), interferon gamma (IFN $\gamma$ ) CD4 T cells, CD8 T cells (CD28+CD27- EM4, or Tc1), invariant natural killer T1 (iNKT1 cells), and IgG3 B cells [15-17]. Innate lymphoid cells 1 (NKp44+CD103- ILC1) is the immune cells helping to initiate TH1 immune reaction [18]. The type 1 ILCs, which are positive for NKp44 (natural cytotoxic receptor), are the typical cytotoxic type 1 innate lymphoid cells secreting IFN $\gamma$ in response to interleukin-12 or interleukin-18. These type $1 \mathrm{NKp} 44+$ ILCs are located in intra-epithelial locations [18,19]. Type 2 myeloid dendritic cells (CD141+ mDC2) are the main antigenpresenting cells that initiate TH1 immune reaction. The driven cytokine for TH1 immunity is interleukin-12. IFN $\gamma$-secreting CD4 T helper cells are the central mediators in the TH1 immunity. Macrophages with IFN $\gamma$ stimulation will be activated to become inflammatory M1 macrophages. IFN $\gamma$ can activate induced nitric oxide synthetase (iNOS) to kill the intercellular organisms in the phagolysosomes of macrophages [20]. The key transcription factors for TH1 immunity are STAT1, STAT4, and T-bet. Interleukin-12 can activate STAT4, and interferon gamma can activate STAT1. IFNg can activate cytotoxic CD8 T cells. CD8 can be categorized into four subgroups according to the expression of CD27 and CD28. CD28+ CD8 T cells are for eradicable immunity, and CD28-CD8 T cells are for tolerable immunity. The CD27 molecule is used for anti-viral immunity, but not for anti-intracellular bacteria, fungi, or protozoa [21]. Cytotoxic T cells 1 (TC1), or so-called Effector-Memory CD8 T cells 4 (CD28+CD27- EM4), are used for TH1 anti-intracellular bacteria, fungi, or protozoa immunity. Cytotoxic T cells 2(Tc2), or so-called Effector-Memory CD8 T cells 1 (CD28+CD27+ EM1), are used for TH $\alpha \beta$ anti-virus immunity [22]. IFN $\gamma$ can induce a B cell class switch to human IgG3 or corresponding murine IgG2b antibody [23]. Invariant natural killer $\mathrm{T}$ cells are immune cells recognizing lipid or glycolipid antigens from pathogens. iNKT1 cells are the subtypes of iNKT cells against intracellular bacteria, fungi, or protozoa. TH1 immunity is the host immune response to intracellular pathogens. The intracellular location is more important than the pathogen type. Thus, TH1 immunity can be triggered to defend against intracellular bacteria, fungi, and protozoa. Activated macrophages are the key effector cells that digest intracellular bacteria, fungi, and protozoa. 
Intracellular protozoa are categorized into the parasite groups. Intracellular protozoa, including Plasmodium, Leishmania, Toxoplasma, Babesia, and Cryptosporidium, can all trigger a TH1 host immune response [24-34]. Intracellular bacteria, such as Chlamydia, and intracellular fungi, such as Histoplasma, can also trigger TH1 immunity. This is the intracellular protozoa-eradicable host immune response. Type 4 hypersensitivity (delayed-type hypersensitivity) is related to TH1 immunity. The whole host immunological pathways against parasitic infections are summarized in Table 1 and Figure 1.

The TH1 immunological pathway includes macrophages (M1), CD8 T cells, iNKT1 cells, IFN $\gamma$-producing CD4 T cells, and IgG3 B cells. The TH1 immune reaction is a host response against intracellular pathogens, including intracellular bacteria, protozoa, and fungi. TH1 immunity is driven by interleukin-12. Type 1 innate lymphoid cells (ILC1) and type 2 myeloid dendritic cells (mDC2) also play important roles in initiating the TH1 immunological reaction. The signaling for transducing the TH1 immune response by interleukin-12 is mediated by JAK2/TYK2 [35]. TYK2 signaling induced by interleukin-12 is stronger than that induced by interleukin-23. IFN $\gamma$ activates STAT1 $\alpha$ via JAK1/JAK2 [36]. This signaling further activates downstream STAT1 $\alpha$ and STAT4 transcription factors, which also activates T-bet transcription. These transcription factors contribute to the TH1 immunological pathway. The TH1 immunological pathway is associated with type 4 delayed-type hypersensitivities, such as tuberculosis reaction, type 1 diabetes, and multiple sclerosis. The JAK/STAT signaling in each host immunological pathway is summarized in Figure 2.

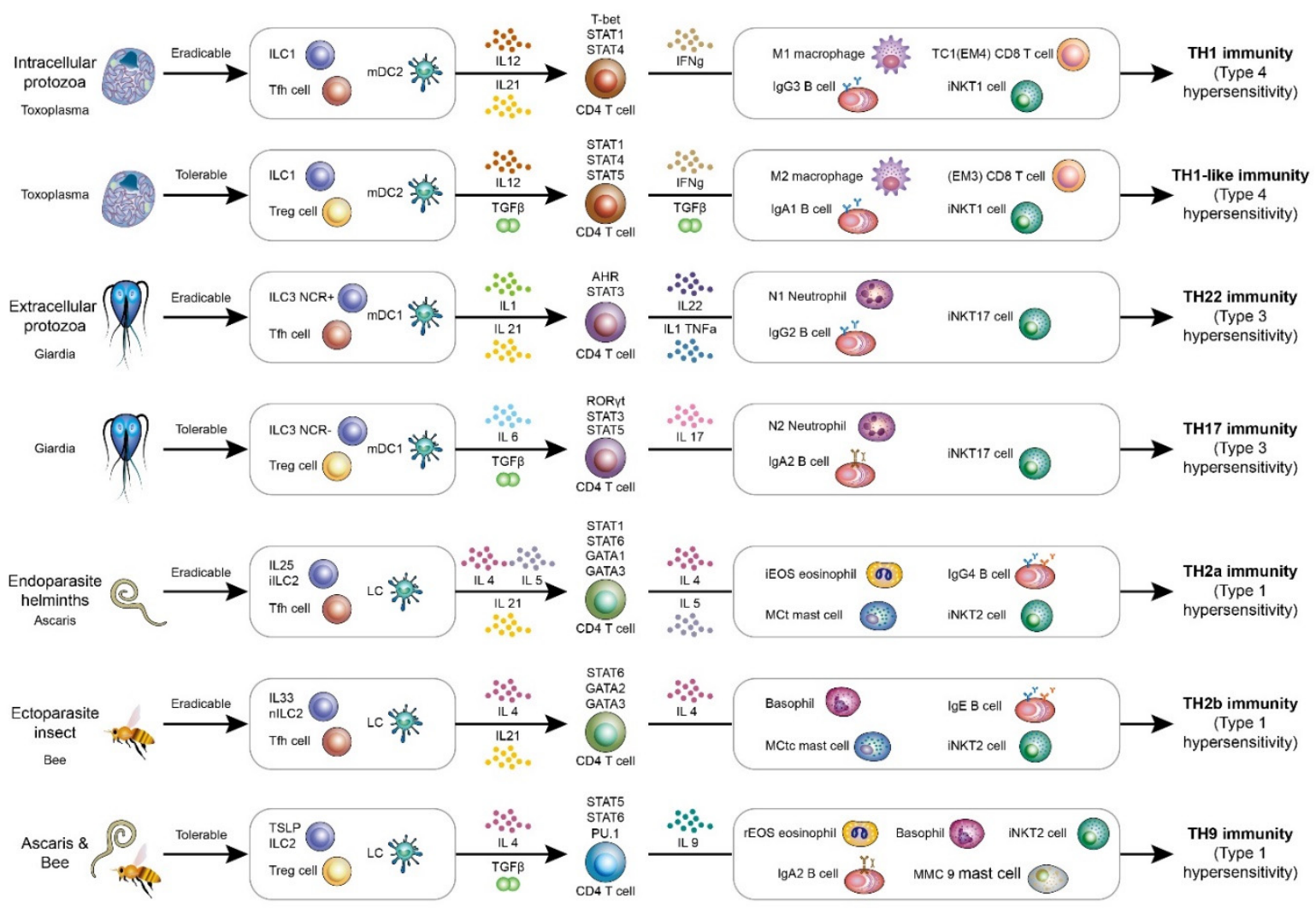

Figure 1. A framework of host immunological pathways against parasitic infections. The host immunological pathways can be divided into Tfh-mediated eradicable (IgG related) or Treg-mediated tolerable (IgA related) immune responses. For intracellular micro-organisms including intercellular protozoa, the eradicable immunity is TH1 immunity, and the tolerable immunity is TH1-like immunity. For extracellular micro-organisms including extracellular protozoa, the eradicable immunity is TH22 immunity, and the tolerable immunity is TH17 immunity. For endoparasites including helminths, the eradicable immunity is TH2a immunity. For ectoparasites including insects, the eradicable immunity is TH2b immunity. For endoparasites and ectoparasites, the tolerable immunity is TH9 immunity. 
Table 1. Summary of host immunological pathways against parasites.

\begin{tabular}{|c|c|c|c|c|c|c|c|c|c|}
\hline $\begin{array}{l}\text { Immune } \\
\text { Pathways }\end{array}$ & Cytokines & $\begin{array}{l}\text { Transcription } \\
\text { Factors }\end{array}$ & $\begin{array}{l}\text { Innate } \\
\text { Lymphoid } \\
\text { Cells }\end{array}$ & Effector Cells & CD4 T Cells & B Cells & NKT Cells & Pathogens & Autoimmunity \\
\hline $\begin{array}{l}\text { TH1 eradicable } \\
\text { immunity }\end{array}$ & IFNg, IL-12 & $\begin{array}{c}\text { STAT1, STAT4, } \\
\text { T-bet }\end{array}$ & ILC1 & $\begin{array}{c}\text { Macrophages } \\
\text { M1 }\end{array}$ & $\begin{array}{l}\text { IFNg CD4 T } \\
\text { cells }\end{array}$ & IgG3 & iNKT1 & $\begin{array}{c}\text { Intracellular } \\
\text { protozoa, bacteria, } \\
\text { and fungi }\end{array}$ & Type 4 DTH \\
\hline $\begin{array}{l}\text { TH1-like } \\
\text { tolerable } \\
\text { immunity }\end{array}$ & IFNg, TGF $\beta$ & $\begin{array}{l}\text { STAT1, STAT4, } \\
\text { STAT5 }\end{array}$ & ILC1 & $\begin{array}{c}\text { Macrophages } \\
\text { M2 }\end{array}$ & $\begin{array}{c}\mathrm{IFNg} / \mathrm{TGF} \beta C D 4 \\
\mathrm{~T} \text { cells }\end{array}$ & $\operatorname{IgA} 1$ & iNKT1 & $\begin{array}{c}\text { Intracellular } \\
\text { protozoa, bacteria, } \\
\text { and fungi }\end{array}$ & Type 4 DTH \\
\hline $\begin{array}{l}\text { TH22 eradicable } \\
\text { immunity }\end{array}$ & IL-1, IL-6, TNF $\alpha$ & STAT3, AHR & ILC3 NCR+ & Neutrophils N1 & $\begin{array}{l}\text { IL-22 CD4 T } \\
\text { cells }\end{array}$ & $\operatorname{IgG} 2$ & iNKT17 & $\begin{array}{c}\text { Extracellular } \\
\text { protozoa, bacteria, } \\
\text { and fungi }\end{array}$ & $\begin{array}{l}\text { Type } 3 \text { immune } \\
\text { complex }\end{array}$ \\
\hline $\begin{array}{l}\text { TH17 tolerable } \\
\text { immunity }\end{array}$ & IL-6, TGF $\beta$ & $\begin{array}{c}\text { STAT3, STAT5, } \\
\text { ROR } \gamma \mathrm{t}\end{array}$ & ILC3 NCR- & Neutrophils N2 & $\begin{array}{l}\text { IL-17 CD4 T } \\
\text { cells }\end{array}$ & $\operatorname{IgA} 2$ & iNKT17 & $\begin{array}{c}\text { Extracellular } \\
\text { protozoa, bacteria, } \\
\text { and fungi }\end{array}$ & $\begin{array}{l}\text { Type } 3 \text { immune } \\
\text { complex }\end{array}$ \\
\hline $\begin{array}{l}\text { TH2a eradicable } \\
\text { immunity }\end{array}$ & IL-4, IL-5 & $\begin{array}{l}\text { STAT6, STAT1, } \\
\text { GATA1/3 }\end{array}$ & IL-25 iILC2 & $\begin{array}{l}\text { Eosinophils } \\
\text { (iEOS), mast } \\
\text { cells (MCt) }\end{array}$ & IL-5 CD4 T cells & IgG4 & iNKT2 & Helminths & $\begin{array}{l}\text { Type } 1 \text { allergy } \\
\text { IgG4 related }\end{array}$ \\
\hline $\begin{array}{l}\text { TH2b eradicable } \\
\text { immunity }\end{array}$ & IL-4, IL-13 & $\begin{array}{l}\text { STAT6, STAT3, } \\
\text { GATA2/3 }\end{array}$ & IL-33 nILC2 & $\begin{array}{l}\text { Basophils, mast } \\
\text { cells (MCct) }\end{array}$ & $\begin{array}{c}\text { IL-4 / IL-13 CD4 } \\
\text { T cells }\end{array}$ & $\operatorname{IgE}$ & iNKT2 & Insects & $\begin{array}{l}\text { Type } 1 \text { allergy } \\
\text { IgE related }\end{array}$ \\
\hline $\begin{array}{l}\text { TH9 tolerable } \\
\text { immunity }\end{array}$ & IL-4, TGF $\beta$ & $\begin{array}{c}\text { STAT6, STAT5, } \\
\text { PU.1 }\end{array}$ & TSLP ILC2 & $\begin{array}{c}\text { Eosinophils } \\
(\mathrm{rEOS}), \\
\text { basophils, mast } \\
\text { cells (MMC9) }\end{array}$ & IL-9 CD4 T cells & $\operatorname{IgA} 2$ & iNKT2 & $\begin{array}{l}\text { Helminths and } \\
\text { Insects }\end{array}$ & Type 1 allergy \\
\hline
\end{tabular}




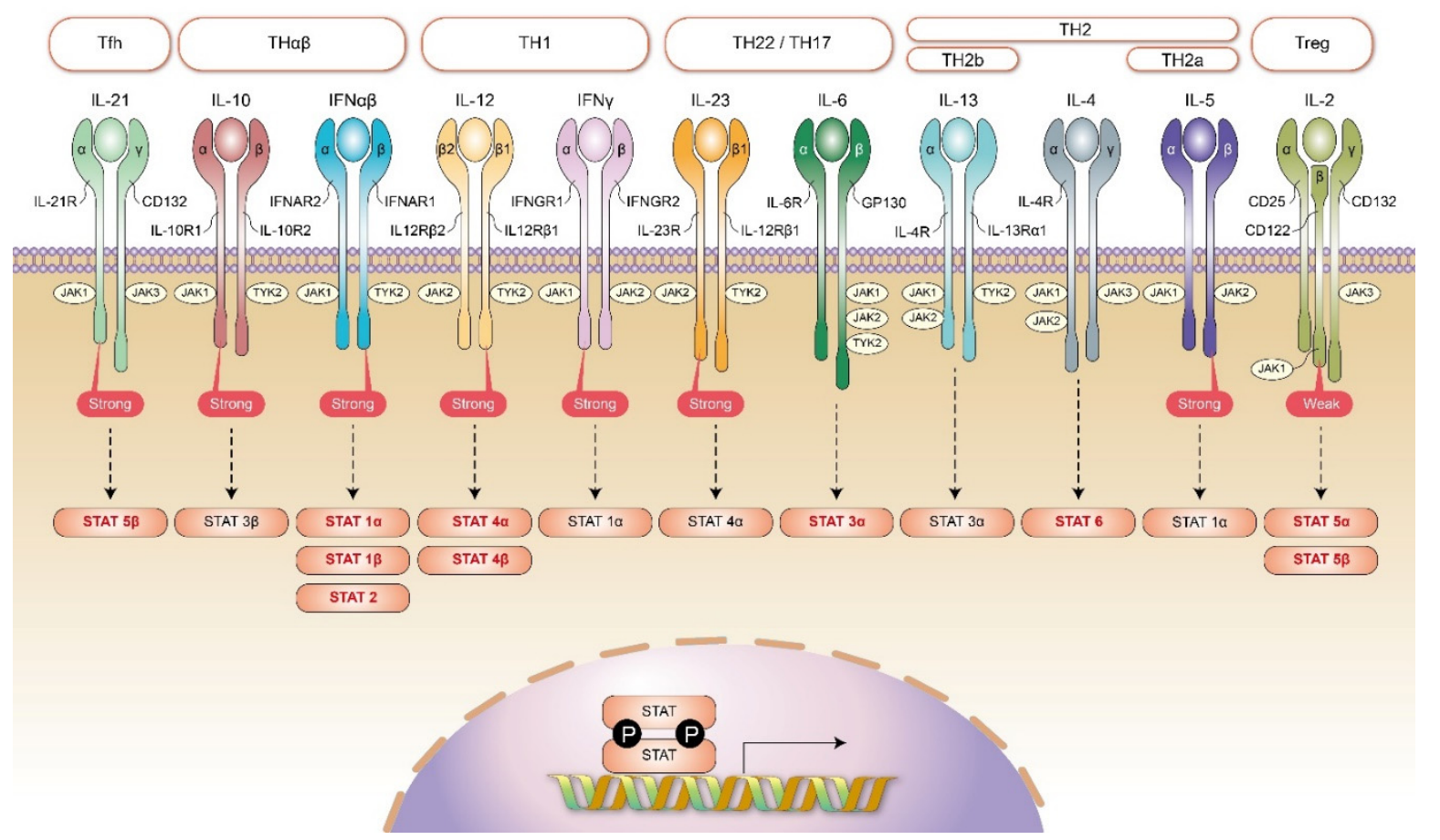

Figure 2. JAK/STAT signaling and the framework of host immunities. In Tfh immune reaction, the key mediating JAK molecules are JAK1 (stronger) and JAK3. They activate downstream STAT5 $\beta$. In Treg immune reaction, the key mediating JAK molecules are JAK1 and JAK3 (stronger). They activate downstream STAT5 $\alpha$ and STAT5 $\beta$. In TH1 immunity, the key cytokine receptors are interleukin-12 and IFN $\gamma$. The key mediating JAK molecules for interleukin-12 receptor are JAK2 and TYK2 (stronger). They activate downstream STAT4 $\alpha$ and STAT4 $\beta$. The key mediating JAK molecules for IFN $\gamma$ receptor are JAK1 (stronger) and JAK2. They activate downstream STAT1 $\alpha$. In TH2 immunity (including TH2a and TH2b immunities), the key cytokine receptor is interleukin-4 receptor. The key mediating JAK molecules for interleukin-4 receptor are JAK1, JAK2, and JAK3. They activate downstream STAT6. In addition, in TH2a immunity, an additional interleukin-5 receptor is needed. The key mediating JAK molecules for interleukin-5 receptor are JAK1 and JAK2 (stronger). They activate downstream STAT $1 \alpha$. Additionally, in TH2b immunity, an additional interleukin-13 receptor is needed. The key mediating JAK molecules for interleukin-13 receptors are JAK1, JAK2, and TYK2. They activate downstream STAT3 $\alpha$. In TH22/TH17 immunity, the key cytokine receptors are interleukin-6 and interleukin-23. The key mediating JAK molecules for interleukin-6 receptor are JAK1, JAK2, and TYK2. They activate downstream STAT3 $\alpha$. The key mediating JAK molecules for interleukin-23 receptor are JAK2 (stronger) and TYK2. They activate downstream STAT4 $\alpha$. In TH $\alpha \beta$ immunity, the key cytokine receptors are IFN $\alpha / \beta$ and interleukin-10. The key JAK molecules for IFN $\alpha / \beta$ are JAK1 and TYK2 (stronger). They activate downstream STAT1 $\alpha$, STAT1 $\beta$, and STAT2. The key JAK molecules for interleukin-10 receptor are JAK1 (stronger) and TYK2. They activate downstream STAT3 $\beta$.

For immune tolerance to intracellular protozoa, the host mounts a TH1-like immune response. The effector cells for TH1-like immunity are macrophages (M2), IFN $\gamma / \mathrm{TGF} \beta$ CD4 T cells, Effector-Memory CD8 T cells 3 (CD28-CD27- EM3), iNKT1 cells, and IgA1 B cells $[16,17]$. Innate lymphoid cell 1 (NKp44- ILC1) is an immune cell that helps to initiate TH1-like immune response. The regulatory type 1 non-cytotoxic innate lymphoid cells without a natural killer receptor marker (NKp44) are located in mucosa to promote TH1like immunity $[37,38]$. Regulatory CD4 T helper cells (Treg) play a critical role in initiating tolerable immune responses. Treg cells can activate STAT5A and STAT5B transcription factors via interleukin-2 [39]. Both STAT5A and STAT5B play non-redundant roles in the regulatory or tolerable immunological pathways. Regulatory dendritic cells (DCreg) also help antigen presentation in the tolerable TH1-like immunity. The effector cells for TH1-like immunity are the alternate activated macrophages (M2 macrophages), which is transformed by TGF $\beta$ and IFN $\gamma$. Alternative activated macrophages M2 are the principal 
cells mediating the TH1-like immunity to intracellular pathogens. IFN $\gamma / \mathrm{TGF} \beta \mathrm{CD} 4 \mathrm{~T}$ cells are the central CD4 T helper cells in mediating TH1-like immunity. Effector-Memory CD8 T cells 3 (CD28-CD27-EM3) are the main cytotoxic T cells targeting the intracellular pathogens in this tolerable immune response [15]. It is worth noting that Effector-Memory CD8 T cells 2 (CD28-CD27+ EM2) are the main cytotoxic T cells against viruses in tolerable host immune response. TGF $\beta$ produced from regulatory $\mathrm{T}$ helper cells can cause $\mathrm{B}$ cell antibody class switch into IgA. Additionally, IgA has two subtypes: $\operatorname{IgA} 1$ is in serum and $\operatorname{IgA} 2$ is in the mucosal surface. For intracellular bacteria, fungi, or protozoa, IgA1 is the major type of IgA antibody in this tolerable host immunity. The key transcription factors for TH1-like immunity are STAT1, STAT4, and STAT5. STAT4 and STAT1 can be activated by interleukin-12 and IFN $\gamma$, respectively. Like TH1 immunity, iNKT1 is a natural killer T cell against intracellular pathogen lipid antigens. TH1-like immunity is a chronic immune tolerance to intracellular pathogens, including intracellular bacteria, protozoa, and fungi. Chronic infections with intracellular protozoa usually trigger the TH1-like immunological pathway. Type 4 hypersensitivity (delayed-type hypersensitivity) is related to TH1-like immunity.

The TH1-like immunological pathway includes alternatively activated macrophages (M2), CD8 T cells, iNKT1 cells, IFN $\gamma$ and TGF $\beta$-producing CD4 T cells, and IgA1-producing $\mathrm{B}$ cells. The TH1-like immune reaction is a host response against intracellular pathogens, including intracellular bacteria, protozoa, and fungi. TH1-like immunity is driven by interleukin- 12 and TGF- $\beta$. Type 1 innate lymphoid cells (ILC1) and type 2 myeloid dendritic cells (mDC2) also play important roles in initiating the TH1 immunological reaction. This signaling activates downstream STAT $5 \alpha / \beta$, STAT $1 \alpha$, and STAT 4 transcription factors. These transcription factors contribute to the TH1 immunological pathway. TH1-like immunological pathway is associated with type 4 delayed-type hypersensitivities, such as tuberculosis reaction, type 1 diabetes, and multiple sclerosis.

\subsection{Extracellular Protozoa and TH22/TH17 Immunity}

For free-living extracellular protozoa, the eradicable host immunological pathway is TH22 immunity with neutrophils (N1), interleukin-22 CD4 T cells, iNKT17 cells, and IgG2 B cells. Innate lymphoid cells 3 (NCR+ ILC3) help to initiate TH22 immunity. Natural cytotoxic receptor (NCR) is positive for the type 3 innate lymphoid cells in initiating the TH22 immunological pathway by secreting interleukin-22. Type 1 myeloid dendritic cells (mDC1) are the antigen-presenting cells for initiating TH22 host immunity. Proinflammatory cytokines, including interleukin-1, TNF- $\alpha$, or interleukin- 6 , can initiate the TH22 immunity against extracellular organisms. These pro-inflammatory cytokines can activate STAT3 transcription factor. Inflammatory type 1 neutrophils (N1) are the major effector cells of the TH22 host immunological pathway. Interleukin-22-producing CD4 T helper cells play central roles in mediating TH22 immunity. The key transcription factors for TH22 immunity are STAT3 and Aryl Hydrocarbon Receptor (AHR). The interleukin22/AHR/STAT3 axis of CD4 T helper cells plays a key role in mediating TH22 immunity. iNKT17 cells are the major NKT cells against lipid or glycolipid antigens from extracellular organisms. IgG2 is the human B cell-producing antibody, which can form an immune complex with soluble extracellular organisms. The TH22 cytokines interleukin- $1 \alpha$ and interleukin- $1 \beta$ are shown to induce B cell isotype switch into human IgG2 antibody [40]. TH22 immunity is the host immune response to extracellular protozoa, bacteria, and fungi. It is worth noting that extracellular location determines the host immunological pathway, which is more important than whether the pathogen is bacteria, fungi, or protozoa. Neutrophils can use neutrophil extracellular traps and kill these extracellular free-living pathogens. These extracellular free-living protozoa include Trypanosoma, Amoebae, Giardia, and Trichomonas [41-48]. These pathogens can induce TH22 host immunity. Extracellular bacteria, such as Escherichia coli, and extracellular fungi, such as Aspergillus, can also trigger $\mathrm{TH} 22$ host immune reactions. Type 3 hypersensitivity (immune complex mediated) is related to TH22 immunity. 
The TH22 immunological pathway includes neutrophils (N1), interleukin-22-producing CD4 T cells, iNKT17 cells, and IgG2 B cells. The TH22 immune reaction is a host response against extracellular bacteria, protozoa, and fungi. TH22 immunity is driven by TNF- $\alpha$ or interleukin-1. Type 3 innate lymphoid cells (ILC3) and type 1 myeloid dendritic cells $(\mathrm{mDC} 1)$ also play important roles in initiating the TH22 immunological reaction. The signaling for transducing the TH22 immune response is mediated by JAK1/JAK2/TYK2, which are downstream signaling molecules of interleukin-6 [49-51]. The signaling activates downstream STAT3 transcription factors. In addition, the aryl hydrocarbon receptor (AHR) is a key mediator of TH22 immunity. Moreover, interleukin- 23 can activate STAT $4 \alpha$ via JAK2/TYK2 signaling [52]. This also helps trigger the TH22/TH17 immune reaction. TH22 immunological pathway is associated with type 3 immune complex hypersensitivities such as Arthus reaction and rheumatoid arthritis.

The immune tolerance pathway against extracellular protozoa, fungi, and bacteria is TH17 immunity. The effector cells of TH17 immunity include neutrophils (N2), interleukin17 CD4 T cells, iNKT17 cells, and IgA2 B cells. Innate lymphoid cells 3 (NCR- ILC3) without the expression of natural cytotoxic receptor (NCR-) are the innate immune cells that help to initiate TH17 immunity by secreting interleukin-17. Regulatory CD4 T helper cells (Treg) play a critical role in initiating tolerable immune responses. Treg cells can activate STAT5A and STAT5B transcription factors via interleukin-2. Both STAT5A and STAT5B play non-redundant roles in the regulatory or tolerable immunological pathways. TGF $\beta$ plus interleukin-6 can trigger the TH17 immunological pathway. Regulatory dendritic cells (DCreg) also help antigen presentation in the tolerable TH17 immunity. Regulatory type 2 neutrophils are the effector cells for TH17 immunity. Interleukin-17-producing CD4 T helper cells play central roles in mediating TH17 immunity. The interleukin$17 / R O R \gamma t / S T A T 3$ axis is the central axis in TH17 immune reaction. The subtype of invariant NKT cells against extracellular organisms' lipid or glycolipid antigens is the iNKT17 cell. TGF $\beta$ produced from regulatory T helper cells can cause B cell antibody class switch into IgA. The subtype IgA2 is in the mucosal surface. For extracellular bacteria, fungi, or protozoa, IgA2 is the major type of IgA antibody in this tolerable host immunity. The key transcription factors for TH17 immunity are STAT3, STAT5, and ROR $\gamma$ t. The TH17 immune reaction is a chronic immune tolerance to extracellular free-living protozoa. Type 3 hypersensitivity (Immune complex mediated) is related to TH17 immunity.

The TH17 immunological pathway includes neutrophils (N2), interleukin-17-producing CD4 T cells, iNKT17 cells, and IgA2 B cells. The TH17 immune reaction is a host response against extracellular bacteria, protozoa, and fungi. TH17 immunity is driven by TNF- $\alpha$ or IL-6 plus TGF- $\beta$. Type 3 innate lymphoid cells (ILC3) and type 1 myeloid dendritic cells (mDC1) also play important roles in initiating the TH17 immunological reaction. The signaling for transducing the TH17 immune response is mediated by JAK1/JAK3 and JAK1/JAK2/TYK2. The signaling activates downstream STAT3 $\alpha$ and STAT5 $\alpha / \beta$ transcription factors. In addition, ROR $\gamma \mathrm{t}$ is also a key mediator of TH17 immunity. The TH17 immunological pathway is associated with type 3 immune complex hypersensitivities, such as Arthus reaction and rheumatoid arthritis.

\subsection{Helminths (Endoparasites) and Eradicable TH2a Immunity}

For helminths (endoparasites), the eradicable host immunological pathway is TH2a immunity with inflammatory eosinophils, interleukin-5/interleukin-4 CD4 T cells, tryptasepositive mast cells (MCt), iNKT2 cells, and IgG4 B cells. The meaning of endoparasites is parasites located in our bodies. Inflammatory innate lymphoid cells 2 (Interleukin-25 induced iILC2) help to initiate TH2a immune response [53,54]. Interleukin-25 can help innate lymphoid cells 2 to produce more interleukin-4, interleukin-5, and interleukin-13, and, in particular, stimulate eosinophil activation. While interleukin-4, interleukin-5, and interleukin- 13 can all be up-regulated by interleukin- 25 stimulation, interleukin- 5 and interleukin-13 are mostly stimulated $[55,56]$. Additionally, interleukin-5 is strongly associated with eosinophil activation. The inflammatory innate lymphoid cells can help the host 
to defend itself against helminth infection initially. Langerhans cells are antigen-presenting cells that help to present antigens to initiate TH2 immune reaction [57]. Inflammatory eosinophils (iEOS) are the major effector cells that use IgG4-mediated antibody-dependent cellular toxicity to attack the helminth tegument [58]. IgG4 antibody is usually associated with eosinophilia. IgG4 subtype is the smallest amount of all IgG antibodies and accounts for 3\% of all antibodies in the blood. Tryptase-positive mast cells are the mast cell subtypes in TH2a immunity. MCt secretes interleukin- 5 and responds to platelet activating factor (PAF), a potent eosinophil chemoattractant and activator [59]. Interleukin-4/interleukin-5producing CD4 $\mathrm{T}$ cells play central roles in mediating TH2a immunity, and interleukin-4 can activate STAT6 to initiate TH2 immunity. Type 2 invariant natural killer T cells (iNKT2) are the iNKT cell subtypes against helminth lipid or glycolipid antigens. This TH2a pathway belongs to TH2 immunity and is a subtype. The letter "a" in TH2a means "acid", which is derived from the name of eosinophils. STAT6, STAT1, GATA1, and GATA3 are key transcription factors in TH2a immunity, which up-regulate interleukin-5 and the function of eosinophils [60-63]. Helminths (endoparasites) that can induce TH2a immunity with eosinophilia include Ascaris, hookworms, tapeworms, pinworms, filarial worms, Toxocara, and Strongyloides [64-73]. However, several helminths can also induce IgE antibodies, so this immune response is a subtype of the TH2 immune response. Type 1 hypersensitivity (allergy) is related to TH2a immunity, and it is a IgG4 dominant type 1 hypersensitivity.

The TH2 immunological pathway includes eosinophils (iEOS), basophils, mast cells, interleukin-4/interleukin-5-producing CD4 T cells, iNKT2 cells, and IgG4/IgE B cells. The TH2 immune reaction is a host response against extracellular helminths and insects. TH2 immunity is driven by interleukin-4. Type 2 innate lymphoid cells (ILC2) and Langerhans cells play important roles in initiating the $\mathrm{TH} 2$ immunological reaction. The signaling for transducing the TH2 immune response is mediated by JAK2/JAK3 [74,75]. This signaling activates the downstream STAT6 transcription factor. In addition, GATA transcription factors are vital to the TH2 immunological pathway. The TH2 immune response can be further divided into two subtypes: TH2a and TH2b. TH2a immunity acts against helminths with eosinophils (iEOS), mast cells, interleukin-5-producing CD4 T cells, iNKT2 cells, and IgG4 B cells. Interleukin-5 activates STAT1 $\alpha$ via JAK1/JAK2 [76]. Compared to interferon gamma, JAK2 signaling induced by interleukin-5 is stronger.

\subsection{Parasitic Insects and Arachnids (Ectoparasites) and Eradicable TH2b Immunity}

For insects (ectoparasites), the eradicable host immunological pathway is TH2b immunity with inflammatory basophils, chymase- and tryptase-positive mast cells (MCct), interleukin-3/interleukin-4 CD4 T cells, iNKT2 cells, and IgE B cells. Ectoparasites means that these insects are located in our bodies' outer skin surface. Nature innate lymphoid cells 2 (interleukin-33 induced nILC2) help to initiate TH2b immune reaction [56,77]. Langerhans cells are antigen-presenting cells responsible for antigen presentation in $\mathrm{TH} 2 \mathrm{~b}$ immunity [57]. The major effector cells of TH2b immunity are basophils and chymaseand tryptase-positive mast cells (MCct). MCct secretes interleukin-4 and interleukin-13 and has a C5a receptor to respond to C5a, an anaphylatoxin that induces IgE-mediated anaphylaxis. Interleukin-33 can also be produced by mast cells to mediate IgE-dominant allergic reaction. Circulating basophils and resident mast cells have the same characteristics. IgE antibody is the least represented antibody in humans, and it only accounts for $0.05 \%$ in peripheral blood. This can be explained by the fact that insect or arachnid infection is a rare event compared to other bacteria or virus infections. The letter " $b$ " in TH2b means "base", which is derived from the name of basophils. STAT6, GATA2, and GATA3 are key transcription factors for TH2b immunity, which up-regulate the function of basophils [60,61]. Interleukin-3/interleukin-4-producing CD4 T helper cells play central roles in mediating TH2b immunity. Interleukin- 4 can activate the TH2 transcription factor STAT6. The subtypes of invariant natural killer T cells are iNKT2 cells combating insect or arachnid lipid or glycolipid antigens. IgE can cause the physical expelling of insects (ectoparasites) via skin itchiness, skin wheal with toxin dilution, rhinorrhea, mucus forma- 
tion and secretion, nausea/vomiting, bronchoconstriction, and increased bowel movement. Basophil accumulation is usually noted at the site of insect bites or dwelling. This can explain why people are allergic to shrimps or crabs with the up-regulation of IgE antibodies. However, these IgE-mediated mechanisms can also expel helminths in the lungs or intestines. Thus, this immune response $(\mathrm{TH} 2 \mathrm{~b})$ is a subtype of the $\mathrm{TH} 2 \mathrm{immune}$ response. The bites of parasitic arachnids and insects, including those of ticks, fleas, and mosquitos, can induce a TH2b immune reaction [78-82]. The stings of non-parasitic insects, such as bees and wasps, also induce a TH2b immune reaction. Type 1 hypersensitivity (allergy) is related to TH2b immunity, and it is IgE-dominant type 1 hypersensitivity.

TH2b immunity acts against insects with basophils, mast cells, interleukin-4/interleukin13-producing CD4 T cells, iNKT2 cells, and IgE B cells. Both TH2a and TH2b immune responses are related to the activation of STAT6. However, GATA transcription factors differ between the two subtypes of immune reactions. In TH2a immunity, GATA1 and GATA3 play crucial roles, whereas in TH2b immunity, GATA2 and GATA3 play crucial roles. STAT3 also plays an important role in TH2b immunity. Interleukin-13 can activate STAT3 $\alpha$ via JAK1, JAK2, and TYK2 [83]. The TH2 immunological pathway is associated with type 1 allergic hypersensitivities, such as asthma, allergic rhinitis, and atopic dermatitis [84].

\subsection{Parasites and Tolerable TH9 Immunity}

The TH9 host immunological pathway is a chronic immune tolerance response to parasites (endoparasites and ectoparasites). The main effector cells of the TH9 immunological pathway include regulatory eosinophils, regulatory basophils, mast cells (MMC9), interleukin-9 CD4 T cells, iNKT2 cells, and IgA2 B cells [58,85]. Thymic stromal lymphopoietin (TSLP)-induced innate lymphoid cells 2 help to initiate TH9 immunity $[56,86]$. Type 2 innate lymphoid cells driven by TSLP produce interleukin-9 and interleukin-13. Thus, type 2 innate lymphoid cells can be categorized into three subtypes: IL-25 driven, IL-33 driven, and TSLP driven. The three subtypes are responsible for different host immunological pathways against parasites including TH2a, TH2b, and TH9. Regulatory CD4 T helper cells (Treg) play a critical role in initiating tolerable immune responses. Treg cells can activate STAT5A and STAT5B transcription factors via interleukin-2. Both STAT5A and STAT5B play non-redundant roles in regulatory or tolerable immunological pathways. TGF $\beta$ plus interleukin-4 can trigger the TH9 immunological pathway. Regulatory dendritic cells (DCreg) also contribute to the antigen presentation in tolerable TH17 immunity. Regulatory eosinophils and regulatory basophils are the effector cells for TH9 immunity. Interleukin-9-producing mast cells (MMC9) are the mast cell subtype responsible for TH9 immunity. Interleukin-9-producing CD4 T helper cells play central roles in mediating TH9 immunity. The subtype of invariant NKT cells against extracellular organisms' lipid or glycolipid antigens is iNKT2 cell. TGF $\beta$ produced from regulatory T helper cells can cause B cell antibody class switch into IgA. The subtype IgA2 is in the mucosal surface. For extracellular parasites, IgA2 is the major type of IgA antibody in this tolerable host immunity. STAT6, STAT5, and PU.1 are key transcription factors for TH9 immunity to up-regulate interleukin-9 [87]. The TH9 driven cytokine intereleukin-4 can activate STAT6 to mediate parasite immunity. Type 1 hypersensitivity (allergy) is related to TH9 immunity, and it is a chronic tolerable immune reaction. Chronic asthma is an example of this TH9 immunological pathway.

The TH9 immunological pathway includes regulatory eosinophils (rEOS), basophils, mast cells (MMC9), interleukin-9-producing CD4 T cells, iNKT2 cells, and IgA2 B cells. The TH2 immune reaction is a host response against extracellular helminths and insects. TH9 immunity is driven by IL-4 and TGF- $\beta$ (from Tregs). Type 2 innate lymphoid cells (ILC2) and Langerhans cells play important roles in initiating the TH9 immunological reaction. The signaling for transducing the TH2 immune response is mediated by JAK2/JAK3 and JAK1/JAK3. This signaling activates downstream STAT6 and STAT5 $\alpha / \beta$ transcription factors. In addition, the PU.1 transcription factor is also vital for the TH9 immunological 
pathway. The TH9 immunological pathway is associated with type 1 allergic hypersensitivities, such as asthma, allergic rhinitis, and atopic dermatitis.

\section{Other Host Immunological Pathways: Immunity against Viruses}

The TH $\alpha \beta$ immunological pathway includes NK cells (NK1), interleukin-10-producing CD4 T cells, iNKT10 cells, and IgG1 B cells $[88,89]$. The TH $\alpha \beta$ immune reaction is an eradicable host response against viruses. TH $\alpha \beta$ immunity is driven by IFN $\alpha / \beta$ or IL-10. Innate lymphoid cells (ILC10) and plasmacytoid dendritic cells play important roles in initiating $\mathrm{TH} \alpha \beta$ immunological reactions. The signaling for transducing the TH $\alpha \beta$ immune response is mediated by JAK1/TYK2 [90,91]. This signaling activates downstream STAT1 $\alpha$, STAT1 $\beta$, and STAT3 $\beta$ transcription factors. In addition, IRF is also a key mediator of TH $\alpha \beta$ immunity [92]. JAK1 signaling induced by interleukin-10 is stronger than that induced by interferon $\alpha / \beta$. The TH $\alpha \beta$ immunological pathway is associated with type 2 antibodydependent cellular cytotoxic hypersensitivities, such as systemic lupus erythematous.

The TH3 immunological pathway includes NK cells (NK2), interleukin-10/TGF $\beta$ producing CD4 T cells, iNKT10 cells, and IgA1 B cells. The TH3 immune reaction is a tolerable host response against viruses. TH3 immunity is driven by IFN $\alpha / \beta$ or interleukin-10 plus TGF- $\beta$. Innate lymphoid cells (ILC10) and plasmacytoid dendritic cells play important roles in initiating the TH3 immunological reaction. The signaling for transducing the TH3 immune response is mediated by JAK1/JAK3 and JAK1/TYK2. The signaling activates downstream STAT $1 \alpha$, STAT1 $\beta$, STAT 2 , STAT $3 \beta$, and STAT $5 \alpha / \beta$ transcription factors. In addition, IRF is a key mediator of TH3 immunity. The TH3 immunological pathway is associated with type 2 antibody-dependent cellular cytotoxic hypersensitivities, such as systemic lupus erythematous.

\section{Future Perspectives}

This host immunological framework against parasitic disorders as well as relevant key JAK/STAT signaling can provide insights to develop drugs or vaccines to control parasitic infections and allergic hypersensitivities. TH1/TH1-like is the host immune reaction against intracellular micro-organisms. IFN $\gamma$ is the key cytokine of TH1/TH1-like immunity to suppress intracellular protozoa. Thus, we could use IFN $\gamma$ to treat malaria or toxoplasma infections. Previous studies also showed that IFN $\gamma$ can totally kill malarial pathogens, especially during early infection [93]. Literature also showed that IFN $\gamma$ can eliminate toxoplasma [94]. Thus, IFN $\gamma$ can be used as a therapeutic agent to treat intracellular protozoa including malaria or Toxoplasma. Vaccines against intracellular protozoa should be able to induce IgG3 in TH1 immune response successfully. TH22/TH17 is the host immune response against extracellular micro-organisms. Interleukin-22 and interleukin17 are the key cytokines in TH22 or TH17 immune responses. Literature showed that interleukin-22 can suppress extracellular protozoa including Trichomonas [44]. Literature also showed that interleukin-17 can control extracellular protozoa such as giardiasis [45]. Thus, interleukin-22/interleukin-17 can be used as therapeutic agents to treat extracellular protozoa including trichomonas or giardiasis. Vaccines against extracellular protozoa should be able to induce IgG2 in TH22 immune response. TH2/TH9 is the host immune response against parasites (endoparasites and ectoparasites). Interleukin-4 and interleukin9 are the key cytokines in TH2/TH9 immunity to inhibit parasites including helminths and insects. Interleukin-4 can suppress intestinal nematode parasites including Strongyles or Trichinella [95]. Interleukin-9 can also enhance host resistance to intestinal nematodes such as Trichuris infection [96]. So, interleukin-4 and interleukin-9 can be used as therapeutic agents to treat infections of helminths or insects. Vaccines against helminths should be able to induce IgG4 in TH2 immunological pathway. In addition, TH2 immunity can be divided into TH2a immunity and TH2b immunity. Because immune reaction against helminths infection belongs to TH2a immunity with IgG4 antibody production. Thus, it is important to initiate TH2a immune reaction against helminths infections. Interleukin5 is the key cytokine in TH2a immunity which can activate eosinophils. Thus, we can 
use interleukin- 5 as a therapeutic agent to treat helminths infections. TH2b immunity with $\operatorname{IgE}$ antibody response is mainly against infections cause by insects. Thus, when we develop a vaccine against helminths, it is better to induce a TH2a immunity with IgG4 antibody response than to induce a TH2b immunity with $\operatorname{IgE}$ antibody response. It is worth noting that we should consider to use eradicable or tolerable cytokines used to treat above infections. When the parasitic infection is too diffuse and extensive such as diffuse infection of toxoplasma, we should use cytokines with tolerable immunity to mildly control the infection to avoid overt organ damage. Thus, our framework against parasitic diseases is very informative for drug or vaccine development for these infections. Besides, the relevant JAK/STAT signaling is also very useful for drug development strategies. JAK inhibitors such as abrocitinib, upadacinib, baricitinib, and gusacitinib have been developed to control allergic diseases including atopic dermatitis [97]. Other JAK inhibitors including ruxolitinib and deglocitinib are also under development to treat atopic dermatitis or food allergy which is associated with parasitic immune responses. It is important to identify allergic disease is TH2a or TH2b immune reaction. For example, allergic asthma is mainly induced by antigens from dust mites, parasitic insects, so TH2b is more likely to be the immune-pathogenesis of asthma. Basophils, IgE, and interleukin-13 play major roles in the TH2b immunopathogenesis. Previous studies using anti-interleukin-5 monoclonal antibody to treat allergic asthma. Even they found out that eosinophil counts decreased after anti-interleukin-5 antibody treatment, the asthmatic symptoms of these patients were not alleviated or only mild-moderate reduction in eosinophilic asthma [98,99]. In noneosinophilic asthma, the effect of anti-interleukin- 5 antibody is doubtful. This could be because that eosinophils, IgG4, and interleukin- 5 are more important to TH2a immunity. Thus, therapeutic agents targeting TH2a immune reaction in asthma may not induce favorable effects. Previous studies also found out that anti-interleukin-13 antibody is more important to alleviate symptoms of allergic asthma [100]. Another review article also pointed out IgE antibody is more important than eosinophil in the immune-pathogenesis of asthma [101]. Thus, our immunological framework against parasitic infections which distinguish $\mathrm{TH} 2 \mathrm{a}$ and $\mathrm{TH} 2 \mathrm{~b}$ immune response can be vital for controlling allergic diseases including asthma. Our framework is very informative to provide hints to control parasite infections as well as allergic hypersensitivities.

\section{Conclusions}

This framework describes the immunological pathways of the human host response to four types of parasitic infections. Intracellular protozoa induce TH1/TH1-like immunity; extracellular protozoa induce TH22/TH17 immunity; endoparasites (helminths) induce TH2a eradicable immunity; and ectoparasites (parasitic insects and arachnids) induce $\mathrm{TH} 2 \mathrm{~b}$ eradicable immunity. TH9 immunity is a tolerable immune response to endoparasites and ectoparasites. In addition, different JAK/STAT signaling is the key in each host immunological pathway against parasitic infections. When we determine the different frameworks for the host immunological pathways against intracellular protozoa, extracellular protozoa, endoparasites (helminths), and ectoparasites (insects), we should use different vaccine or drug development strategies to control these infections. Malarial pathogens are intercellular protozoa. Thus, we can use IFN $\gamma$ from TH1/TH1-like immunity to control malarial infection. The host immune responses against parasites are related to hypersensitivities, including allergic reaction, such as asthma or atopic dermatitis. Once we determine the host immunities against parasitic infections, we can develop better vaccines or therapeutic agents to control these parasites, as well as these hypersensitivities. Drugs targeting master JAK/STAT signaling can also be developed to treat parasitic infections or hypersensitivities, including allergic responses, which are either IgE-dominant (controlling STAT3 $\alpha$ and STAT6) or IgG4-dominant (controlling STAT1 $\alpha$ and STAT6) reactions. 
Author Contributions: Conceptualization, W.-C.H.; methodology, W.-C.H.; validation, K.-W.T., M.T.L. and K.-C.L.; formal analysis, W.-C.H.; investigation, W.-C.H.; writing-original draft preparation, T.-H.W. and Y.-J.W.; writing-review and editing, W.-C.H.; visualization, T.-H.W. and Y.-J.W.; supervision, W.-C.H.; project administration, K.-W.T. and K.-C.L.; funding acquisition, W.-C.H. All authors have read and agreed to the published version of the manuscript.

Funding: A grant was received from Taipei Tzu Chi Hospital (grant number TCRD-TPE-110-45).

Institutional Review Board Statement: Not applicable.

Informed Consent Statement: Not applicable.

Data Availability Statement: Not applicable.

Acknowledgments: The author is grateful for the instructions provided by Alan Scott, Louis August Bourgeois, and Pien-Chien Huang during his PhD study in the Department of International Health, Johns Hopkins University, Bloomberg School of Public Health. The author is also grateful for the guidance from Chi-Huey Wong and Alice Lin-Tsing Yu in his postdoctoral research at the Genomics Research Center of Academia Sinica, Taiwan. The author wishes to thank Ingrid Kuo for creating the illustration used herein.

Conflicts of Interest: The authors declare that the manuscript was written in the absence of any commercial or financial relationships that could be construed as a potential conflict of interest.

\section{References}

1. Hu, W.C. A Framework of All Discovered Immunological Pathways and Their Roles for Four Specific Types of Pathogens and Hypersensitivities. Front. Immunol. 2020, 11, 1992. [CrossRef]

2. $\mathrm{Hu}, \mathrm{W} . \mathrm{C}$. Human immune responses to Plasmodium falciparum infection: Molecular evidence for a suboptimal TH $\alpha \beta$ and TH17 bias over ideal and effective traditional TH1 immune response. Malar. J. 2013, 12, 392. [CrossRef]

3. Gao, Q.; Liang, X.; Shaikh, A.S.; Zang, J.; Xu, W.; Zhang, Y. JAK/STAT Signal Transduction: Promising Attractive Targets for Immune, Inflammatory and Hematopoietic Diseases. Curr. Drug Targets 2018, 19, 487-500. [CrossRef]

4. Morris, R.; Kershaw, N.J.; Babon, J.J. The molecular details of cytokine signaling via the JAK/STAT pathway. Protein Sci. 2018, 27, 1984-2009. [CrossRef] [PubMed]

5. Owen, K.L.; Brockwell, N.K.; Parker, B.S. JAK-STAT Signaling: A Double-Edged Sword of Immune Regulation and Cancer Progression. Cancers 2019, 11, 2002. [CrossRef]

6. Seif, F.; Khoshmirsafa, M.; Aazami, H.; Mohsenzadegan, M.; Sedighi, G.; Bahar, M. The role of JAK-STAT signaling pathway and its regulators in the fate of T helper cells. Cell Commun. Signal 2017, 15, 23. [CrossRef]

7. Villarino, A.V.; Kanno, Y.; O'Shea, J.J. Mechanisms and consequences of Jak-STAT signaling in the immune system. Nat. Immunol. 2017, 18, 374-384. [CrossRef] [PubMed]

8. Xin, P.; Xu, X.; Deng, C.; Liu, S.; Wang, Y.; Zhou, X.; Ma, H.; Wei, D.; Sun, S. The role of JAK/STAT signaling pathway and its inhibitors in diseases. Int. Immunopharmacol. 2020, 80, 106210. [CrossRef]

9. Yao, Y.; Chen, C.L.; Yu, D.; Liu, Z. Roles of follicular helper and regulatory T cells in allergic diseases and allergen immunotherapy. Allergy 2021, 76, 456-470. [CrossRef]

10. Crotty, S. T Follicular Helper Cell Biology: A Decade of Discovery and Diseases. Immunity 2019, 50, 1132-1148. [CrossRef] [PubMed]

11. Scheeren, F.A.; Diehl, S.A.; Smit, L.A.; Beaumont, T.; Naspetti, M.; Bende, R.J.; Blom, B.; Karube, K.; Ohshima, K.; van Noesel, C.J.; et al. IL-21 is expressed in Hodgkin lymphoma and activates STAT5: Evidence that activated STAT5 is required for Hodgkin lymphomagenesis. Blood 2008, 111, 4706-4715. [CrossRef] [PubMed]

12. Spolski, R.; Gromer, D.; Leonard, W.J. The gamma c family of cytokines: Fine-tuning signals from IL-2 and IL-21 in the regulation of the immune response. F1000Res 2017, 6, 1872. [CrossRef]

13. Burchill, M.A.; Yang, J.; Vogtenhuber, C.; Blazar, B.R.; Farrar, M.A. IL-2 receptor beta-dependent STAT5 activation is required for the development of Foxp3+ regulatory T cells. J. Immunol. 2007, 178, 280-290. [CrossRef]

14. Kirken, R.A.; Rui, H.; Malabarba, M.G.; Howard, O.M.; Kawamura, M.; O'Shea, J.J.; Farrar, W.L. Activation of JAK3, but not JAK1, is critical for IL-2-induced proliferation and STAT5 recruitment by a COOH-terminal region of the IL-2 receptor beta-chain. Cytokine 1995, 7, 689-700. [CrossRef]

15. Romero, P.; Zippelius, A.; Kurth, I.; Pittet, M.J.; Touvrey, C.; Iancu, E.M.; Corthesy, P.; Devevre, E.; Speiser, D.E.; Rufer, N. Four functionally distinct populations of human effector-memory CD8+ T lymphocytes. J. Immunol. 2007, 178, 4112-4119. [CrossRef]

16. Krovi, S.H.; Gapin, L. Invariant Natural Killer T Cell Subsets-More Than Just Developmental Intermediates. Front. Immunol. 2018, 9, 1393. [CrossRef] [PubMed]

17. Tuttle, K.D.; Krovi, S.H.; Zhang, J.; Bedel, R.; Harmacek, L.; Peterson, L.K.; Dragone, L.L.; Lefferts, A.; Halluszczak, C.; Riemondy, K.; et al. TCR signal strength controls thymic differentiation of iNKT cell subsets. Nat. Commun. 2018, 9, 2650. [CrossRef] [PubMed] 
18. Jiao, Y.; Huntington, N.D.; Belz, G.T.; Seillet, C. Type 1 Innate Lymphoid Cell Biology: Lessons Learnt from Natural Killer Cells. Front. Immunol. 2016, 7, 426. [CrossRef]

19. Fuchs, A.; Vermi, W.; Lee, J.S.; Lonardi, S.; Gilfillan, S.; Newberry, R.D.; Cella, M.; Colonna, M. Intraepithelial type 1 innate lymphoid cells are a unique subset of IL-12- and IL-15-responsive IFN-gamma-producing cells. Immunity 2013, 38, 769-781. [CrossRef] [PubMed]

20. Xuan, W.; Qu, Q.; Zheng, B.; Xiong, S.; Fan, G.H. The chemotaxis of M1 and M2 macrophages is regulated by different chemokines. J. Leukoc. Biol. 2015, 97, 61-69. [CrossRef] [PubMed]

21. Tomiyama, H.; Takata, H.; Matsuda, T.; Takiguchi, M. Phenotypic classification of human CD8+ T cells reflecting their function: Inverse correlation between quantitative expression of CD27 and cytotoxic effector function. Eur. J. Immunol. 2004, 34, 999-1010. [CrossRef]

22. Kemp, R.A.; Backstrom, B.T.; Ronchese, F. The phenotype of type 1 and type 2 CD8+ T cells activated in vitro is affected by culture conditions and correlates with effector activity. Immunology 2005, 115, 315-324. [CrossRef] [PubMed]

23. Gracie, J.A.; Bradley, J.A. Interleukin-12 induces interferon-gamma-dependent switching of IgG alloantibody subclass. Eur. J. Immunol. 1996, 26, 1217-1221. [CrossRef] [PubMed]

24. Cabantous, S.; Poudiougou, B.; Traore, A.; Keita, M.; Cisse, M.B.; Doumbo, O.; Dessein, A.J.; Marquet, S. Evidence that interferon-gamma plays a protective role during cerebral malaria. J. Infect. Dis. 2005, 192, 854-860. [CrossRef] [PubMed]

25. Sedegah, M.; Finkelman, F.; Hoffman, S.L. Interleukin 12 induction of interferon gamma-dependent protection against malaria. Proc. Natl. Acad. Sci. USA 1994, 91, 10700-10702. [CrossRef] [PubMed]

26. Castellano, L.R.; Filho, D.C.; Argiro, L.; Dessein, H.; Prata, A.; Dessein, A.; Rodrigues, V. Th1/Th2 immune responses are associated with active cutaneous leishmaniasis and clinical cure is associated with strong interferon-gamma production. Hum. Immunol. 2009, 70, 383-390. [CrossRef] [PubMed]

27. Suzuki, Y.; Orellana, M.A.; Schreiber, R.D.; Remington, J.S. Interferon-gamma: The major mediator of resistance against Toxoplasma gondii. Science 1988, 240, 516-518. [CrossRef]

28. Ehigiator, H.N.; McNair, N.; Mead, J.R. Cryptosporidium parvum: The contribution of Th1-inducing pathways to the resolution of infection in mice. Exp. Parasitol. 2007, 115, 107-113. [CrossRef] [PubMed]

29. Gowda, D.C.; Wu, X. Parasite Recognition and Signaling Mechanisms in Innate Immune Responses to Malaria. Front. Immunol. 2018, 9, 3006. [CrossRef] [PubMed]

30. Lima, T.S.; Lodoen, M.B. Mechanisms of Human Innate Immune Evasion by Toxoplasma gondii. Front. Cell Infect. Microbiol. 2019, 9, 103. [CrossRef]

31. Mukhopadhyay, D.; Arranz-Solís, D.; Saeij, J.P.J. Influence of the Host and Parasite Strain on the Immune Response During Toxoplasma Infection. Front. Cell Infect. Microbiol. 2020, 10, 580425. [CrossRef]

32. Rodríguez-Serrato, M.A.; Salinas-Carmona, M.C.; Limón-Flores, A.Y. Immune response to Leishmania mexicana: The hostparasite relationship. Pathog. Dis. 2020, 78. [CrossRef]

33. Sasai, M.; Pradipta, A.; Yamamoto, M. Host immune responses to Toxoplasma gondii. Int. Immunol. 2018, 30, 113-119. [CrossRef] [PubMed]

34. Yam, X.Y.; Preiser, P.R. Host immune evasion strategies of malaria blood stage parasite. Mol. Biosyst. 2017, 13, $2498-2508$. [CrossRef] [PubMed]

35. Floss, D.M.; Klocker, T.; Schroder, J.; Lamertz, L.; Mrotzek, S.; Strobl, B.; Hermanns, H.; Scheller, J. Defining the functional binding sites of interleukin 12 receptor beta1 and interleukin 23 receptor to Janus kinases. Mol. Biol. Cell 2016, 27, 2301-2316. [CrossRef] [PubMed]

36. Kohlhuber, F.; Rogers, N.C.; Watling, D.; Feng, J.; Guschin, D.; Briscoe, J.; Witthuhn, B.A.; Kotenko, S.V.; Pestka, S.; Stark, G.R.; et al. A JAK1/JAK2 chimera can sustain alpha and gamma interferon responses. Mol. Cell Biol. 1997, 17, 695-706. [CrossRef]

37. Bernink, J.H.; Peters, C.P.; Munneke, M.; te Velde, A.A.; Meijer, S.L.; Weijer, K.; Hreggvidsdottir, H.S.; Heinsbroek, S.E.; Legrand, N.; Buskens, C.J.; et al. Human type 1 innate lymphoid cells accumulate in inflamed mucosal tissues. Nat. Immunol. 2013, 14, 221-229. [CrossRef] [PubMed]

38. Panda, S.K.; Colonna, M. Innate Lymphoid Cells in Mucosal Immunity. Front. Immunol. 2019, 10, 861. [CrossRef] [PubMed]

39. Barsheshet, Y.; Wildbaum, G.; Levy, E.; Vitenshtein, A.; Akinseye, C.; Griggs, J.; Lira, S.A.; Karin, N. CCR8(+)FOXp3(+) Treg cells as master drivers of immune regulation. Proc. Natl. Acad. Sci. USA 2017, 114, 6086-6091. [CrossRef] [PubMed]

40. Ishihara, Y.; Zhang, J.B.; Fakher, M.; Best, A.M.; Schenkein, H.A.; Barbour, S.E.; Tew, J.G. Non-redundant roles for interleukin-1 alpha and interleukin-1 beta in regulating human IgG2. J. Periodontol. 2001, 72, 1332-1339. [CrossRef]

41. Cai, C.W.; Blase, J.R.; Zhang, X.; Eickhoff, C.S.; Hoft, D.F. Th17 Cells Are More Protective Than Th1 Cells Against the Intracellular Parasite Trypanosoma cruzi. PLoS Pathog. 2016, 12, e1005902. [CrossRef] [PubMed]

42. Guo, X.; Barroso, L.; Lyerly, D.M.; Petri, W.A., Jr.; Houpt, E.R. CD4+ and CD8+ T cell- and IL-17-mediated protection against Entamoeba histolytica induced by a recombinant vaccine. Vaccine 2011, 29, 772-777. [CrossRef]

43. Suryawanshi, A.; Cao, Z.; Sampson, J.F.; Panjwani, N. IL-17A-mediated protection against Acanthamoeba keratitis. J. Immunol. 2015, 194, 650-663. [CrossRef] [PubMed]

44. Makinde, H.M.; Zariffard, R.; Mirmonsef, P.; Novak, R.M.; Jarrett, O.; Landay, A.L.; Spear, G.T. IL-22 Levels are Associated withTrichomonas vaginalisInfection in the Lower Genital Tract. Am. J. Reprod. Immunol. 2013, 70, 38-44. [CrossRef] 
45. Singer, S.M. Control of Giardiasis by Interleukin-17 in Humans and Mice-Are the Questions All Answered? Clin. Vaccine Immunol. 2016, 23, 2-5. [CrossRef]

46. Belkaid, Y.; Harrison, O.J. Homeostatic Immunity and the Microbiota. Immunity 2017, 46, 562-576. [CrossRef]

47. Mercer, F.; Johnson, P.J. Trichomonas vaginalis: Pathogenesis, Symbiont Interactions, and Host Cell Immune Responses. Trends Parasitol. 2018, 34, 683-693. [CrossRef]

48. Uribe-Querol, E.; Rosales, C. Immune Response to the Enteric Parasite Entamoeba histolytica. Physiology (Bethesda) 2020, 35, 244-260. [CrossRef]

49. Kaptein, A.; Paillard, V.; Saunders, M. Dominant negative stat3 mutant inhibits interleukin-6-induced Jak-STAT signal transduction. J. Biol. Chem. 1996, 271, 5961-5964. [CrossRef]

50. Backert, I.; Koralov, S.B.; Wirtz, S.; Kitowski, V.; Billmeier, U.; Martini, E.; Hofmann, K.; Hildner, K.; Wittkopf, N.; Brecht, K.; et al . STAT3 activation in Th17 and Th22 cells controls IL-22-mediated epithelial host defense during infectious colitis. J. Immunol. 2014, 193, 3779-3791. [CrossRef]

51. Yu, C.Y.; Wang, L.; Khaletskiy, A.; Farrar, W.L.; Larner, A.; Colburn, N.H.; Li, J.J. STAT3 activation is required for interleukin-6 induced transformation in tumor-promotion sensitive mouse skin epithelial cells. Oncogene 2002, 21, 3949-3960. [CrossRef] [PubMed]

52. Lee, P.W.; Smith, A.J.; Yang, Y.; Selhorst, A.J.; Liu, Y.; Racke, M.K.; Lovett-Racke, A.E. IL-23R-activated STAT3/STAT4 is essential for Th1/Th17-mediated CNS autoimmunity. JCI Insight 2017, 2. [CrossRef]

53. Pei, C.; Zhao, C.; Wang, A.J.; Fan, A.X.; Grinchuk, V.; Smith, A.; Sun, R.; Xie, Y.; Lu, N.; Urban, J.F., Jr.; et al. Critical Role for Interleukin-25 in Host Protective Th2 Memory Response against Heligmosomoides polygyrus bakeri. Infect. Immun. 2016, 84, 3328-3337. [CrossRef] [PubMed]

54. Huang, Y.; Guo, L.; Qiu, J.; Chen, X.; Hu-Li, J.; Siebenlist, U.; Williamson, P.R.; Urban, J.F., Jr.; Paul, W.E. IL-25-responsive, lineage-negative KLRG1(hi) cells are multipotential 'inflammatory' type 2 innate lymphoid cells. Nat. Immunol. 2015, 16, 161-169. [CrossRef]

55. Fort, M.M.; Cheung, J.; Yen, D.; Li, J.; Zurawski, S.M.; Lo, S.; Menon, S.; Clifford, T.; Hunte, B.; Lesley, R.; et al. IL-25 induces IL-4, IL-5, and IL-13 and Th2-associated pathologies in vivo. Immunity 2001, 15, 985-995. [CrossRef]

56. Camelo, A.; Rosignoli, G.; Ohne, Y.; Stewart, R.A.; Overed-Sayer, C.; Sleeman, M.A.; May, R.D. IL-33, IL-25, and TSLP induce a distinct phenotypic and activation profile in human type 2 innate lymphoid cells. Blood Adv. 2017, 1, 577-589. [CrossRef] [PubMed]

57. Klechevsky, E.; Morita, R.; Liu, M.; Cao, Y.; Coquery, S.; Thompson-Snipes, L.; Briere, F.; Chaussabel, D.; Zurawski, G.; Palucka, A.K.; et al. Functional specializations of human epidermal Langerhans cells and CD14+ dermal dendritic cells. Immunity 2008, 29, 497-510. [CrossRef]

58. Mesnil, C.; Raulier, S.; Paulissen, G.; Xiao, X.; Birrell, M.A.; Pirottin, D.; Janss, T.; Starkl, P.; Ramery, E.; Henket, M.; et al. Lung-resident eosinophils represent a distinct regulatory eosinophil subset. J. Clin. Investig. 2016, 126, 3279-3295. [CrossRef] [PubMed]

59. Vliagoftis, H.; Lacy, P.; Luy, B.; Adamko, D.; Hollenberg, M.; Befus, D.; Moqbel, R. Mast cell tryptase activates peripheral blood eosinophils to release granule-associated enzymes. Int. Arch. Allergy Immunol. 2004, 135, 196-204. [CrossRef]

60. Ranganath, S.; Murphy, K.M. Structure and specificity of GATA proteins in Th2 development. Mol. Cell Biol. 2001, 21, 2716-2725. [CrossRef]

61. Zon, L.I.; Yamaguchi, Y.; Yee, K.; Albee, E.A.; Kimura, A.; Bennett, J.C.; Orkin, S.H.; Ackerman, S.J. Expression of mRNA for the GATA-binding proteins in human eosinophils and basophils: Potential role in gene transcription. Blood 1993, 81, 3234-3241. [CrossRef]

62. van der Bruggen, T.; Caldenhoven, E.; Kanters, D.; Coffer, P.; Raaijmakers, J.A.; Lammers, J.W.; Koenderman, L. Interleukin-5 signaling in human eosinophils involves JAK2 tyrosine kinase and Stat1 alpha. Blood 1995, 85, 1442-1448. [CrossRef]

63. Pazdrak, K.; Stafford, S.; Alam, R. The activation of the Jak-STAT 1 signaling pathway by IL-5 in eosinophils. J. Immunol. 1995, 155, 397-402. [PubMed]

64. Klion, A.D.; Nutman, T.B. The role of eosinophils in host defense against helminth parasites. J. Allergy Clin. Immunol. 2004, 113, 30-37. [CrossRef]

65. Mitre, E.; Masure, D.; Vlaminck, J.; Wang, T.; Chiers, K.; Van den Broeck, W.; Vercruysse, J.; Geldhof, P. A Role for Eosinophils in the Intestinal Immunity against Infective Ascaris suum Larvae. PLoS Negl. Trop. Dis. 2013, 7, e2138. [CrossRef]

66. Wright, V.; Bickle, Q. Immune responses following experimental human hookworm infection. Clin. Exp. Immunol. 2005, 142, 398-403. [CrossRef] [PubMed]

67. Minciullo, P.L.; Cascio, A.; Isola, S.; Gangemi, S. Different clinical allergological features of Taenia solium infestation. Clin. Mol. Allergy 2016, 14, 18. [CrossRef]

68. Schroeder, J.C.; Jones, D.; Maranich, A. Peripheral Eosinophilia Found in Pediatric Enterobius vermicularis Infections. Clin. Pediatr. 2019, 58, 13-16. [CrossRef] [PubMed]

69. Kim, H.B.; Seo, J.W.; Lee, J.H.; Choi, B.S.; Park, S.G. Evaluation of the prevalence and clinical impact of toxocariasis in patients with eosinophilia of unknown origin. Korean J. Intern. Med. 2017, 32, 523-529. [CrossRef]

70. Bakhtiar, N.M.; Spotin, A.; Mahami-Oskouei, M.; Ahmadpour, E.; Rostami, A. Recent advances on innate immune pathways related to host-parasite cross-talk in cystic and alveolar echinococcosis. Parasites Vectors 2020, 13, 232. [CrossRef] [PubMed] 
71. Gazzinelli-Guimaraes, P.H.; Nutman, T.B. Helminth parasites and immune regulation. F1000Res 2018, 7. [CrossRef] [PubMed]

72. Joardar, N.; Mondal, C.; Sinha Babu, S.P. A review on the interactions between dendritic cells, filarial parasite and parasite-derived molecules in regulating the host immune responses. Scand. J. Immunol. 2021, 93, e13001. [CrossRef] [PubMed]

73. Prodjinotho, U.F.; Lema, J.; Lacorcia, M.; Schmidt, V.; Vejzagic, N.; Sikasunge, C.; Ngowi, B.; Winkler, A.S.; Prazeres da Costa, C. Host immune responses during Taenia solium Neurocysticercosis infection and treatment. PLoS Negl. Trop. Dis. 2020, 14, e0008005. [CrossRef] [PubMed]

74. Malabarba, M.G.; Kirken, R.A.; Rui, H.; Koettnitz, K.; Kawamura, M.; O'Shea, J.J.; Kalthoff, F.S.; Farrar, W.L. Activation of JAK3, but not JAK1, is critical to interleukin-4 (IL4) stimulated proliferation and requires a membrane-proximal region of IL4 receptor alpha. J. Biol. Chem. 1995, 270, 9630-9637. [CrossRef]

75. Palmer-Crocker, R.L.; Hughes, C.C.; Pober, J.S. IL-4 and IL-13 activate the JAK2 tyrosine kinase and Stat6 in cultured human vascular endothelial cells through a common pathway that does not involve the gamma c chain. J. Clin. Investig. 1996, 98, 604-609. [CrossRef] [PubMed]

76. Ogata, N.; Kouro, T.; Yamada, A.; Koike, M.; Hanai, N.; Ishikawa, T.; Takatsu, K. JAK2 and JAK1 Constitutively Associate With an Interleukin-5 (IL-5) Receptor $\alpha$ and $\beta c$ Subunit, Respectively, and Are Activated Upon IL-5 Stimulation. Blood 1998, 91, $2264-2271$. [CrossRef]

77. Hsu, C.L.; Neilsen, C.V.; Bryce, P.J. IL-33 is produced by mast cells and regulates IgE-dependent inflammation. PLoS ONE 2010, 5 , e11944. [CrossRef]

78. Sakakibara, Y.; Wada, T.; Muraoka, M.; Matsuda, Y.; Toma, T.; Yachie, A. Basophil activation by mosquito extracts in patients with hypersensitivity to mosquito bites. Cancer Sci. 2015, 106, 965-971. [CrossRef] [PubMed]

79. Karasuyama, H.; Tabakawa, Y.; Ohta, T.; Wada, T.; Yoshikawa, S. Crucial Role for Basophils in Acquired Protective Immunity to Tick Infestation. Front. Physiol. 2018, 9, 1769. [CrossRef] [PubMed]

80. Halliwell, R.E.; Schemmer, K.R. The role of basophils in the immunopathogenesis of hypersensitivity to fleas (Ctenocephalides felis) in dogs. Vet. Immunol. Immunopathol. 1987, 15, 203-213. [CrossRef]

81. Erdmann, S.M.; Sachs, B.; Kwiecien, R.; Moll-Slodowy, S.; Sauer, I.; Merk, H.F. The basophil activation test in wasp venom allergy: Sensitivity, specificity and monitoring specific immunotherapy. Allergy 2004, 59, 1102-1109. [CrossRef]

82. Cichocka-Jarosz, E.; Dorynska, A.; Pietrzyk, J.J.; Spiewak, R. Laboratory markers of mast cell and basophil activation in monitoring rush immunotherapy in bee venom-allergic children. Immunotherapy 2011, 3, 1013-1017. [CrossRef] [PubMed]

83. Roy, S.; Liu, H.Y.; Jaeson, M.I.; Deimel, L.P.; Ranasinghe, C. Unique IL-13Ralpha2/STAT3 mediated IL-13 regulation detected in lung conventional dendritic cells, $24 \mathrm{~h}$ post viral vector vaccination. Sci. Rep. 2020, 10, 1017. [CrossRef]

84. He, H.; Guttman-Yassky, E. JAK Inhibitors for Atopic Dermatitis: An Update. Am. J. Clin. Dermatol. 2019, 20, 181-192. [CrossRef] [PubMed]

85. Chen, C.Y.; Lee, J.B.; Liu, B.; Ohta, S.; Wang, P.Y.; Kartashov, A.V.; Mugge, L.; Abonia, J.P.; Barski, A.; Izuhara, K.; et al. Induction of Interleukin-9-Producing Mucosal Mast Cells Promotes Susceptibility to IgE-Mediated Experimental Food Allergy. Immunity 2015, 43, 788-802. [CrossRef] [PubMed]

86. Verma, M.; Liu, S.; Michalec, L.; Sripada, A.; Gorska, M.M.; Alam, R. Experimental asthma persists in IL-33 receptor knockout mice because of the emergence of thymic stromal lymphopoietin-driven IL-9(+) and IL-13(+) type 2 innate lymphoid cell subpopulations. J. Allergy Clin. Immunol. 2018, 142, 793-803.e8. [CrossRef] [PubMed]

87. Gerlach, K.; Hwang, Y.; Nikolaev, A.; Atreya, R.; Dornhoff, H.; Steiner, S.; Lehr, H.A.; Wirtz, S.; Vieth, M.; Waisman, A.; et al. TH9 cells that express the transcription factor PU.1 drive T cell-mediated colitis via IL-9 receptor signaling in intestinal epithelial cells. Nat. Immunol. 2014, 15, 676-686. [CrossRef] [PubMed]

88. Hu, W.C. The Central THalphabeta Immunity Associated Cytokine: IL-10 Has a Strong Anti-Tumor Ability Toward Established Cancer Models In Vivo and Toward Cancer Cells In Vitro. Front. Oncol. 2021, 11, 655554. [CrossRef]

89. Geginat, J.; Vasco, M.; Gerosa, M.; Tas, S.W.; Pagani, M.; Grassi, F.; Flavell, R.A.; Meroni, P.; Abrignani, S. IL-10 producing regulatory and helper T-cells in systemic lupus erythematosus. Semin. Immunol. 2019, 44, 101330. [CrossRef]

90. Gauzzi, M.C.; Velazquez, L.; McKendry, R.; Mogensen, K.E.; Fellous, M.; Pellegrini, S. Interferon-alpha-dependent activation of Tyk2 requires phosphorylation of positive regulatory tyrosines by another kinase. J. Biol. Chem. 1996, 271, 20494-20500. [CrossRef]

91. Caldenhoven, E.; van Dijk, T.B.; Solari, R.; Armstrong, J.; Raaijmakers, J.A.; Lammers, J.W.; Koenderman, L.; de Groot, R.P. STAT3beta, a splice variant of transcription factor STAT3, is a dominant negative regulator of transcription. J. Biol. Chem. 1996, 271, 13221-13227. [CrossRef]

92. Mogensen, T.H. IRF and STAT Transcription Factors-From Basic Biology to Roles in Infection, Protective Immunity, and Primary Immunodeficiencies. Front. Immunol. 2018, 9, 3047. [CrossRef]

93. McCall, M.B.; Sauerwein, R.W. Interferon- $\gamma$-central mediator of protective immune responses against the pre-erythrocytic and blood stage of malaria. J. Leukoc. Biol. 2010, 88, 1131-1143. [CrossRef]

94. Nishiyama, S.; Pradipta, A.; Ma, J.S.; Sasai, M.; Yamamoto, M. T cell-derived interferon- $\gamma$ is required for host defense to Toxoplasma gondii. Parasitol. Int. 2020, 75, 102049. [CrossRef] [PubMed]

95. Urban, J.F., Jr.; Katona, I.M.; Paul, W.E.; Finkelman, F.D. Interleukin 4 is important in protective immunity to a gastrointestinal nematode infection in mice. Proc. Natl. Acad. Sci. USA 1991, 88, 5513-5517. [CrossRef] [PubMed]

96. Faulkner, H.; Renauld, J.C.; Van Snick, J.; Grencis, R.K. Interleukin-9 enhances resistance to the intestinal nematode Trichuris muris. Infect. Immun. 1998, 66, 3832-3840. [CrossRef] 
97. Cartron, A.M.; Nguyen, T.H.; Roh, Y.S.; Kwatra, M.M.; Kwatra, S.G. Janus kinase inhibitors for atopic dermatitis: A promising treatment modality. Clin. Exp. Dermatol. 2021, 46, 820-824. [CrossRef]

98. Farne, H.A.; Wilson, A.; Powell, C.; Bax, L.; Milan, S.J. Anti-IL5 therapies for asthma. Cochrane Database Syst Rev. 2017, 9, Cd010834. [CrossRef] [PubMed]

99. Leckie, M.J.; ten Brinke, A.; Khan, J.; Diamant, Z.; O’Connor, B.J.; Walls, C.M.; Mathur, A.K.; Cowley, H.C.; Chung, K.F.; Djukanovic, R.; et al. Effects of an interleukin-5 blocking monoclonal antibody on eosinophils, airway hyper-responsiveness, and the late asthmatic response. Lancet 2000, 356, 2144-2148. [CrossRef]

100. Corren, J.; Lemanske, R.F.; Hanania, N.A.; Korenblat, P.E.; Parsey, M.V.; Arron, J.R.; Harris, J.M.; Scheerens, H.; Wu, L.C.; Su, Z.; et al. Lebrikizumab treatment in adults with asthma. N. Engl. J. Med. 2011, 365, 1088-1098. [CrossRef] [PubMed]

101. Matucci, A.; Vultaggio, A.; Maggi, E.; Kasujee, I. Is IgE or eosinophils the key player in allergic asthma pathogenesis? Are we asking the right question? Respir. Res. 2018, 19, 113. [CrossRef] 